\title{
Entrevista: \\ Conversación con Leonardo Paduraa a propósito del tema de esta edición de la revista: exilios, refugio, destierro... y viajes
}

\author{
Ruben Daniel Méndez Castiglioni ${ }^{2}$ \\ José Vicente Ballester ${ }^{3}$ \\ Luiz Gonzaga Lopes ${ }^{4}$
}

RC/JB/LL: Podría contarnos algo de sus lecturas, de sus influencias...

LP: Son muchos los autores de lengua española que uno va leyendo. Incluso a veces, miras hacia atrás, hacia los clásicos, pensando en ese fenómeno de qué cosa somos y de dónde venimos y a través de la literatura uno puede intentar entender. Yo hice mi tesis de grado universitario sobre el inca Garcilaso de la Vega. Yo creo que fue una predestinación que, con 23 años, decidiera convertirme en garcilacista algo que ya nadie era, y fui a buscar los orígenes. Y esa búsqueda de los orígenes me ha llevado a una constante búsqueda de orígenes literarios, históricos, sociales que de alguna manera caracterizan lo que yo he hecho. El estudio de Alejo Carpentier que yo tengo, tiene que ver con eso, mi periodismo tuvo mucho que ver con eso, la historia del barrio chino de la Habana, de dónde salió el ron Bacardi, la historia de la Virgen de la Caridad del Cobre, que es la patrona de Cuba, de dónde salió... siempre he estado buscando... Y eso te lleva a leer literatura de determinadas épocas. Por ejemplo, del Siglo de Oro me interesan los cronistas de la conquista de América, que son unos episodios absolutamente enloquecidos que únicamente leyéndolos y volviéndolos a leer entiendes que pasó en la cabeza de esa gente que estaba descubriendo, realmente descubriendo, un mundo completamente mágico y maravilloso.

RC/JB/LL: ¿Usted se considera un escritor esencialmente cubano?

LP: Miguel de Unamuno decía: "Hemos de hallar lo universal en las entrañas de lo local, y en lo circunscrito y limitado, lo eterno". Y es lo que yo he hecho con Cuba. Pero a veces siento que es inevitable encontrar otros espacios como en El hombre que amaba los perros, porque Moscú, México, España, Turquía, Noruega, París, eran escenarios por los que pasaban sus personajes. Yo recuerdo que fuimos a buscar un día la casa donde Trotsky se había escondido en París, una callecita pequeñita, llegué a ese lugar porque, para mi, reconocer el lugar físico a la hora de escribir es muy importante. Moscú fue muy importante porque yo tenía una imagen de Moscú que tenía que ver con la literatura y con el cine, pero cuando llegué me di cuenta de que había confundido las proporciones, lo que yo pensaba que era del tamaño de este edificio era cinco veces más grande, todo era

1 Consagrado autor de, entre otras obras, La novela de mi vida (2001), La neblina del ayer (2005), El hombre que amaba a los perros (2009) y Herejes (2013).

2 Professor do Instituto de Letras da Universidade Federal do Rio Grande do Sul - Bolsista de Produtividade em Pesquisa do CNPq.

3 Diretor do Instituto Cervantes de Porto Alegre.

4 Jornalista do Correio do Povo. 
mucho más exagerado. Esas proporciones las encontré ahí. Y cuando yo fui a Ámsterdam, para ir a la casa de Rembrandt, había hecho ya toda una investigación sobre esa ciudad porque había viajado muchísimo pero no había ido a Holanda, entonces nos fuimos mi esposa y yo a ese país. Muchas cosas son importantes para la literatura, una de ellas es el conocimiento físico del lugar.

RC/JB/LL: ¿Cómo llega a ese conocimiento físico?

LP: Yo siempre digo que el escritor, si su oficio le permite ganar suficiente dinero para seguir escribiendo, es la cantidad de dinero perfecta. $Y$ esa cantidad de dinero te puede permitir en un momento determinado sacar un billete de avión y hospedarte en un hotel y conocer un lugar. Y después están los lugares que uno va conociendo a lo largo de los viajes. Para mi escribir sobre Madrid o Barcelona, en el sentido de lo físico, me costaría mucho trabajo, crear un personaje madrileño un personaje catalán real; puedo poner a un cubano a vivir en Madrid o en Barcelona porque conozco el ambiente y conozco las reacciones de los cubanos de allí. Respeto mucho el conocimiento de las personas que viven en un lugar y que son de ese lugar. Porque es muy difícil, si no has convivido profundamente con ellos, poder tener ese conocimiento. Mi literatura ha tenido la necesidad de encontrar ese universal cubano que está en lo circunscripto limitado, también conectarlo con otras geografías, otros momentos históricos, y hago todos esos recorridos. La portada de mi libro La transparencia del tiempo es una foto que hizo mi esposa Lucía durante el recorrido que hicimos por el Pirineo Catalán, buscando el pueblito donde podría estar Isabel.

$\mathbf{R C / J B / L L : ~ U s t e d ~ i n v e n t a ~ e l ~ v a l l e . . . ~}$

LP: Invento el valle y todo, pero está inspirado en un valle real... ¿bueno qué es real?

RC/JB/LL: En El hombre que amaba los perros impresionó mucho esa descripción que hace de la Lubianka y la calle vacía donde no se acercaba nadie, a diferencia de las otras calles de Moscú. Eso, evidentemente, si no pasó por allí es muy difícil de describir.

LP: Es muy difícil. Yo he intentado hacer la investigación lo más profunda posible en el sentido histórico, pero si lo puedo completar con la apropiación física del lugar, me es muy importante. Y Ámsterdam fue muy fácil porque la estructura de Ámsterdam sigue siendo la misma del siglo XVII, a la vez que se construyeron los tres anillos, de los tres grandes canales, el canal del Príncipe, del Rey y de la Reina, Ámsterdam quedó un poco dentro de eso. Ámsterdam es perfecta.

RC/JB/LL: Muchos escritores latinoamericanos se exiliaron a lo largo del siglo XX por diversos motivos, principalmente para alejarse de feroces dictaduras, y escribieron en España, Francia... Actualmente algunos optan por viajar y establecerse en Europa y otros se quedan en sus países realizando su labor literaria, como usted, por ejemplo.

LP: Hay casos en que la necesidad te obliga a moverte y hay casos en que es una decisión personal moverte. A veces un poco obligado. Roberto Bolaño, por ejemplo, terminó vi- 
viendo en el norte de Cataluña y Juan Gabriel Vásquez vive en Barcelona hace un tiempo. Pero la mayoría de los escritores prefiere estar en la cercanía con su lugar de origen y de cultura porque es donde tú tienes la mejor comprensión del mundo en que tu vives y de la persona que tú eres, incluso de la lengua que tú hablas. Yo me paso dos meses en Madrid y es inevitable que termine diciéndole a la gente "vale". Es la manera de salir, de pronto, de una situación, yo nunca digo "vale", en Cuba decimos "ok", es un anglicismo que hemos asumido, pero es la solución cubana al "vale" español. Es muy complicado. El exilio siempre es dramático y para el escritor puede ser incluso castrante.

RC/JB/LL: ¿Hubiera sido más fácil para Gabriel García Márquez escribir en Colombia su Cien años de soledad?

LP: No sé. Gabo fue como una especie de vagabundo, prefirió moverse por distintos lugares. Alejo Carpentier vivió en Francia, vivió en Venezuela, terminó de escribir en Venezuela El reino de este mundo, escribió, Los pasos perdidos, El acoso y casi completa El siglo de las luces. Era un escritor que escribe prácticamente fuera de Cuba y después, los otros libros que escribe, los escribe viviendo en París. Como agregado cultural, podía hacerlo, además su literatura no participaba de la realidad cotidiana de esa manera un poco directa que tiene la mía o que tiene las novelas de Pepe Carballo con respecto a Barcelona. Vázquez Montalbán decía que pretendía que lo enterraran en el Camp Nou, porque, decía, “yo soy de Barcelona, yo no soy español, soy catalán”.

RC/JB/LL: Y esto nos lleva nuevamente a la frase de Unamuno...

LP: Exactamente eso: "Hemos de hallar lo universal en las entrañas de lo local, y en lo circunscrito y limitado, lo eterno". Lo circunscrito y limitado es la condición humana y en la condición humana está lo eterno. Milan Kundera dice que la razón de ser de la novela es el desvelamiento de la condición humana. Y cuando le cayeron a palos por todas partes a Gustave Flaubert porque publicó Madame Bovary, en una carta en la que trata de defenderse, dijo: yo lo único que quería era llegar al alma de las cosas. Y es así.

RC/JB/LL: Para algunas obras fue condición necesaria que existiera el exilio, por ejemplo, Rayuela, de Julio Cortázar no se entiende si no se piensa en el exilio. Cuando Cortázar escribe sobre Buenos Aires, lo hace de manera nostálgica, se nota que él está en París, en su París físico. Él está expatriado y su Buenos Aires es lejano. En esa obra se ve muy bien la relación del autor transterrado.

LP: Es que yo creo que no se puede generalizar. Jorge Luis Borges podría haber escrito su poesía en cualquier parte del mundo. A Cortázar la experiencia de París le permitió escribir Rayuela y así es todo. ¿Cuántos años lleva Vargas Llosa fuera de Perú? Ha sido un turista en Perú.

RC/JB/LL: Pero sus novelas siempre vuelven a Perú.

LP: Sus novelas siempre llevan a Perú, su última novela Cinco esquinas, es una novela muy peruana. 
RC/JB/LL: Sus grandes novelas las escribe en Europa. ¿Podemos decir que necesitó mudarse para escribirlas?

LP: Sí, y sin embargo yo necesito las cercanías. Muñoz Molina vive la mitad del año en Nueva York y la otra mitad en España, y cuando más escribe es cuando está en Nueva York, porque es cuando está más tranquilo. Pero hubo un momento en los años setenta en que se crea una literatura del exilio en América Latina.

RC/JB/LL: Muchos exilios son voluntarios...

LP: Carlos Fuentes permaneció en México y daba su curso en los Estados Unidos, estaba en la cercanía de México. Y Juan Rulfo ni se movió de ahí. Están todas las posibilidades.

RC/JB/LL: A algunos escritores el exilio les impide escribir, a otros les estimula.

LP: La cubanía de la obra de José Lezama Lima, por ejemplo. ¿Por dónde uno le entra a Lezama cuando habla de Dafne? Lezama fue únicamente un mes a Jamaica, nunca salió de la isla. Y María Zambrano decía, "Lezama es de Cuba, como Santo Tomás es de Aquino y Sófocles es de Atenas.” Lezama tiene una cubanía complicada. María Zambrano lo entendió, pero ella también era muy complicada.

Recebido em: 16/09/2019; Aceito em: 20/09/2019 